\title{
Water Quality Index of Waste Stabilisation Ponds and Downstream of Discharge Point
}

\author{
Obenne Pearl Gopolang1,2, Moatlhodi Wise Letshwenyo ${ }^{1,2^{*}}$ (i) \\ ${ }^{1}$ Department of Civil and Environmental Engineering, Faculty of Engineering and Technology, Palapye, Botswana \\ ${ }^{2}$ Botswana International University of Science and Technology, Palapye, Botswana \\ Email: obenne.gopolang@studentmail.biust.ac.bw, *letshwenyom@biust.ac.bw
}

How to cite this paper: Gopolang, O.P. and Letshwenyo, M.W. (2019) Water Quality Index of Waste Stabilisation Ponds and Downstream of Discharge Point. Journal of Environmental Protection, 10, 993-1005. https://doi.org/10.4236/jep.2019.108059

Received: June 20, 2019

Accepted: August 10, 2019

Published: August 13, 2019

Copyright () 2019 by author(s) and Scientific Research Publishing Inc. This work is licensed under the Creative Commons Attribution International License (CC BY 4.0).

http://creativecommons.org/licenses/by/4.0/

(c) (i) Open Access

\begin{abstract}
Water quality index has been used in various researches for the assessment of water quality for various uses and discharges into the environment. The purpose of this study was to determine the water quality index of the effluent from waste stabilisation ponds and $400 \mathrm{~m}$ beyond discharge point. This was achieved by evaluating concentrations of seven parameters from soil, eleven physiochemical parameters from effluent and four microbiological parameters. Corresponding water quality indices calculated from microbiological parameters were 854,142, 96 and 1539 respectively, at sites 1, 2, 3 and 4 . Reductions of magnesium, zinc, lead, sodium adsorption ratio, sodium and electrical conductivity in soil samples at site 4 were $15.5 \%, 57 \%, 81.6 \%$, $93.5 \%, 93.5 \%$ and $99 \%$ respectively. The percentage increases were $21.4 \%$ and $185 \%$ respectively, for calcium and iron ions. It can be concluded that the water quality index of the waste stabilisation ponds is unsuitable for discharge into the environment. However, the results revealed improved quality downstream of discharge point.
\end{abstract}

\section{Keywords}

Microbiological Parameters, Physiochemical Parameters, Sodium Absorption Ratio, Soil Sampling, Waste Stabilization Ponds, Water Quality Index

\section{Introduction}

Population growth, climate change, drought and increasing demand for water have negatively affected water resources. Effluent discharges of domestic, industrial and agricultural activities have impaired water quality [1]. The use of surface waters for various purposes threatens the integrity of the ecosystems because of the changes in quality and quantity [2]. Monitoring of effluent dis- 
charges into the environment to minimise pollution is important [1]. There is need to look for alternative water resources and wastewater has been identified as a possible source.

Water quality indices (WQI) methods have been used to monitor the quality of discharged effluent. The calculations are based on evaluating drinking water quality index (DWQI) and irrigation water quality index (IWQI). Studies have been conducted in rivers and wells to monitor their quality. Reference [3] evaluated drinking and irrigation water quality indices in 109 extraction wells in Karaj Plain, Tehran and Alborz provinces. The results revealed 52 wells in good class and 57 wells in poor class for DWQI. As for IWQI, 63 wells were in excellent quality, 36 in good and 10 in poor condition. [4] assessed groundwater quality and evaluated its quality for irrigation in an area covering $38.94 \mathrm{~km}^{2}$ in Ethiopia and reported that, only electrical conductivity, sodium adsorption ratio, sodium, chloride and hydrogen carbonate ions did not meet the requirements.

Some studies have been conducted to evaluate the impact of effluent discharges on sediments along the river bed. For instance, [5] conducted a study on Tigris River in Turkey and found that metal concentrations were higher near the discharge point of a copper mine and decreased downstream.

Few studies have been conducted to calculate the water quality index of effluent resulting from wastewater treatment systems. In addition, no studies are known that have calculated the quality of resulting effluent from the treatment systems along the receiving environment at defined intervals. Furthermore, no such studies have been conducted in Botswana to assess the water quality index of the effluent from treatment systems.

The purpose of this study was therefore to evaluate the water quality index for waste stabilisation ponds system. The associated objectives were 1) to calculate water quality index of effluent at the outlet of the treatment works; 2) to calculate water quality index at a distance of $400 \mathrm{~m}$ from discharge point at $100 \mathrm{~m}$ intervals; 3) to evaluate impact of effluent on receiving soil at intervals of $100 \mathrm{~m}$ from discharge point.

\section{Study Area}

The wastewater treatment facility is located in Palapye village, $70 \mathrm{~km}$ north of Tropic of Capricorn. The geographical location of the village is $22.55^{\circ} \mathrm{S}$ and $27.13^{\circ} \mathrm{E}$ and $926 \mathrm{~m}$ above sea level. The 2011 housing and population census recorded a population of 37000 people. Average annual day temperature varies from $23^{\circ} \mathrm{C}$ to $34^{\circ} \mathrm{C}$ with average annual night temperatures ranging from $6^{\circ} \mathrm{C}$ to $17^{\circ} \mathrm{C}$. The sewage facility was commissioned in 1997 for a population equivalent of 34,740 . The design peak wet weather flow was $139 \mathrm{l} / \mathrm{s}$.

\section{Materials and Methods}

\subsection{Water Quality Index}

Water Quality Index (WQI) is a method widely used for drinking and irrigation 
water quality. It serves as a representation of overall quality of water for public or any intended use as well as in the pollution abatement programs and water quality management. Different water quality parameters are used for the calculation of WQI depending on the uses of water. The procedure for calculating WQI was as per [6]. By comparing the monitored values with the regulatory standards, it combines data into a single number that describes the nature of the water source [7].

WQI was calculated using the method described by [6]. In this study, 10 physico-chemical and 4 biological parameters were chosen to calculate the WQI using the threshold values set by Botswana Bureau of Standards for discharge into the receiving environments. Physio-chemical parameters selected for this study were total dissolved solids (TDS), $\mathrm{pH}$, fluoride, iron, sodium, sodium adsorption ratio, bicarbonate, chloride, nitrate, sulphates, and manganese.

Calculation of WQI was made by using the following equation:

$$
\mathrm{WQI}=\frac{\sum(Q i W i)}{\sum W i}
$$

The quality rating scale $(Q i)$ was calculated by using the following expression:

$$
Q i=100\left[\frac{V i-V o}{S i-V o}\right]
$$

where

$V i$ is estimated concentration of $i$ th parameter in the analysed water;

$V o$ is the ideal value for pure water which is 0 (except $\mathrm{pH}=7.0, \mathrm{DO}=14.6$ );

$S i$ is recommended standard value of ith parameter.

Calculation of unit weight ( $W i)$ for each water quality parameter was calculated as:

$$
W i=\frac{K}{S i}
$$

Where $K=$ proportionality constant, which is calculated using the following equation:

$$
K=\frac{1}{\sum\left(\frac{1}{S i}\right)}
$$

Table 1 below shows the classification of water quality according to water quality

Table 1. Classification of water quality based on WQI method as described by [8].

\begin{tabular}{ccc}
\hline WQI & Status & Possible uses \\
\hline $0-25$ & Excellent & Drinking, irrigational and Industrial \\
$26-50$ & Good & Domestic, Irrigation and industrial \\
$51-75$ & Poor & Irrigation \\
$76-100$ & Very Poor & Restricted use for Irrigation \\
Above 100 & Unfit for drinking & Proper treatment required before use \\
\hline
\end{tabular}


index and possible uses of such waters.

\subsection{Water Sample Analysis}

Physiochemical and microbiological parameters were analysed according to Standard Methods (1998) in the laboratory. Temperature, pH, TDS, and EC were measured on site using portable multiparameter Testr $^{\mathrm{TM}} 35$ series meter supplied by Thermo Fisher Scientific. Samples were then placed in a cooler with ice parks $\left(4^{\circ} \mathrm{C}\right)$ and transported to the laboratory for analysis.

\subsection{Soil Sampling}

Composite soil samples were collected at a depth of $0.2 \mathrm{~m}$ as per the procedure of [9] from ground surface using a soil auger and placed into polythene bags and sealed. Sampling points were at $100 \mathrm{~m}$ intervals from treatment facility outlet point. Samples were placed in a cooler, $4^{\circ} \mathrm{C}$ and transported to the laboratory for analysis. Parameters analysed were electrical conductivity, magnesium, sodium, iron, lead, zinc and calcium. Soil samples were diluted in water at a ratio of 1:2.5. Electrical conductivity EC was measured on site using portable multiparameter Testr $^{\mathrm{TM}} 35$ series meter supplied by Thermo Fisher Scientific. Soil samples were analysed as per [10] procedure. Soil samples were firstly prepared. $30 \mathrm{~g}$ of soil samples were dried at $105^{\circ} \mathrm{C} .1 .0$ gram of sample was weighed and $5 \mathrm{ml}$ of concentration nitric acid (Merck, 99.99\%) was added to each sample. The sample was then heated at $80^{\circ} \mathrm{C}$ until near dryness. Addition of acid and heating process was repeated twice and water added to the residue. The suspension was filtered through Whatman Merck filter paper of $0.45 \mu \mathrm{m}$ pores and the filtrate diluted by deionized water to final volume of $50 \mathrm{ml}$. Sodium, Magnesium and Calcium ions were determined in the laboratory using Flame photometry.

The concentrations of Sodium, Magnesium and Calcium ions were used to calculate the sodium adsorption ratio (SAR) using equation described by [11].

$$
\mathrm{SAR}=\frac{\mathrm{Na}^{+}}{\frac{\sqrt{\mathrm{Ca}^{2+}+\mathrm{Mg}^{2+}}}{2}}
$$

where SAR is the Sodium Adsorption Ratio,

$\mathrm{Na}^{+}$is the concentration of Sodium ions $(\mathrm{mg} / \mathrm{l})$,

$\mathrm{Ca}^{2+}$ is the concentration of Calcium ions $(\mathrm{mg} / \mathrm{l})$,

$\mathrm{Mg}^{2+}$ is the concentration of Magnesium ions (mg/l).

\section{Results and Discussions}

\subsection{Physico-Chemical Water Quality Index}

The calculated physiochemical water quality index is 138 as shown in Table 2 . Since this value is above 100, the effluent is unsuitable for discharge into the environment and cannot be used for irrigation purposes. Further treatment before discharge or use is required. The results indicate that the treatment facility does 
Table 2. Water quality index of the outlet (Site 1) as revealed by physiochemical parameters.

\begin{tabular}{ccccccc}
\hline Parameter & $\begin{array}{c}\text { Observed } \\
\text { value }(\mathrm{Vi})\end{array}$ & $\begin{array}{c}\text { Standard } \\
\text { value }(\mathrm{Si})\end{array}$ & $1 / \mathrm{Si}$ & $\mathrm{Wi}$ & $\begin{array}{c}\text { Quality } \\
\text { rating }(\mathrm{Qi})\end{array}$ & WiQi \\
\hline Fluoride $\left(\mathrm{mg} \cdot \mathrm{L}^{-1}\right)$ & $0.62 \pm 0.64$ & 2 & 0.5 & 0.044 & 31 & 1.37 \\
Iron $\left(\mathrm{mg} \cdot \mathrm{L}^{-1}\right)$ & $0.34 \pm 1.13$ & 2 & 0.5 & 0.044 & 17 & 0.75 \\
Manganese $\left(\mathrm{mg} \cdot \mathrm{L}^{-1}\right)$ & $0.15 \pm 2.26$ & 0.1 & 10 & 0.89 & 150 & 132.86 \\
Nitrate $\left(\mathrm{mg} \cdot \mathrm{L}^{-1}\right)$ & $241 \pm 3.75$ & 30 & 0.03 & 0.003 & 803 & 2.37 \\
Sodium $\left(\mathrm{mg} \cdot \mathrm{L}^{-1}\right)$ & $83.1 \pm 2.44$ & 400 & 0.003 & 0.0002 & 20.8 & 0.005 \\
Sodium absorption ratio & $2.89 \pm 5.61$ & 8 & 0.125 & 0.01 & 36.1 & 0.4 \\
Sulphates & $30.3 \pm 10.8$ & 200 & 0.005 & 0.0004 & 15.1 & 0.007 \\
Total dissolved solids $\left(\mathrm{mg} \cdot \mathrm{L}^{-1}\right)$ & $594 \pm 2.34$ & 2000 & 0.0005 & 0.00004 & 29.7 & 0.001 \\
Bicarbonate $\left(\mathrm{mg} \cdot \mathrm{L}^{-1}\right)$ & $54.7 \pm 4.63$ & 92 & 0.01 & 0.001 & 59.5 & 0.06 \\
Chloride $\left(\mathrm{mg} \cdot \mathrm{L}^{-1}\right)$ & $59.3 \pm 6.57$ & 600 & 0.002 & 0.0002 & 9.89 & 0.001 \\
pH & $6.95 \pm 0.31$ & 8.4 & 0.12 & 0.01 & -3.57 & -0.04 \\
& & & $\Sigma 11.30$ & $\Sigma 1.00$ & & $\Sigma 137.79$
\end{tabular}

not meet the national standard for the country. From Table 2, it can be observed that only manganese ion concentration exceeded the discharge limit, otherwise the effluent quality could be better. The product of quality rating (qi) and weight associated with water quality (Wi) for manganese ion is 132.86 , much higher than the rest. The effluent is discharged into the environment which has no natural water course otherwise dilution would immediately improve the water quality to an acceptable level. Reference [12] reported that when sufficient dilution water is available in the receiving body, then physico-chemical properties concentrations in the receiving body may not reach a critical level. Earlier studies conducted on the treatment system had established that the effective hydraulic efficiency was lower compared to design value which could have led to low performance of the system.

Water quality index of site $2100 \mathrm{~m}$ from the outlet (Site 1) is presented in $\mathrm{Ta}$ ble 3. The water quality index is 67 and is categorised as poor but can be used for irrigation purposes. The results indicate an improvement in quality as the effluent travels from Site 1 to Site 2. Even though water is of poor quality the results show a decrease in WQI value indicating that some degree of natural purification has occurred. The highest reduction in concentration was $53 \%$ observed in manganese ion. Other reductions ranged from $1.5 \%$ to $8 \%$ which contributed to better quality of the effluent. Self-purification is a process which results from mineralization of organic substances, nitrification-denitrification, sedimentation, and assimilation, as well as from dilution and mixing processes [12]. The process and rate of self-purification are influenced by temperature, nature of organic pollutants, and hydraulic characteristics of the receiving environment. This could have contributed to improved quality as the effluent underwent 
self-purification through the natural processes such as adsorption of ions onto soil, and mineralisation.

The water quality index for site 3,200 m downstream of the outlet is 11.0 as shown in Table 4. The quality of the water is classified as excellent and can be used for drinking, irrigation and industrial purposes. The results further indicate self-purification and natural processes occurred as wastewater travelled downstream of the discharge point. The results are comparable to the findings by [13]

Table 3. Water quality index of Site 2 as revealed by physiochemical parameters.

\begin{tabular}{|c|c|c|c|c|c|c|}
\hline Parameter & Observed value (Vi) & Standard value $(\mathrm{Si})$ & $1 / \mathrm{Si}$ & $\mathrm{Wi}$ & Quality rating (Qi) & WiQi \\
\hline Fluoride (mg/l) & $0.6 \pm 0.59$ & 2 & 0.5 & 0.044 & 30 & 1.33 \\
\hline Iron $(\mathrm{mg} / \mathrm{l})$ & $0.5 \pm 0.87$ & 2 & 0.5 & 0.044 & 25 & 1.11 \\
\hline Manganese (mg/l) & $0.07 \pm 1.75$ & 0.1 & 10 & 0.89 & 70 & 62.00 \\
\hline Nitrate $(\mathrm{mg} / \mathrm{l})$ & $224 \pm 2.36$ & 30 & 0.03 & 0.003 & 748 & 2.21 \\
\hline Sodium (mg/l) & $79.3 \pm 4.84$ & 400 & 0.003 & 0.0002 & 19.8 & 0.004 \\
\hline Sodium absorption ratio & $3.16 \pm 5.27$ & 8 & 0.13 & 0.01 & 39.5 & 0.44 \\
\hline Sulphates (mg/l) & $27.8 \pm 6.95$ & 200 & 0.005 & 0.0004 & 13.9 & 0.006 \\
\hline Total dissolved solids (mg/l) & $578 \pm 24.7$ & 2000 & 0.0005 & 0.00004 & 29.9 & 0.001 \\
\hline Bicarbonate (mg/l) & $53.9 \pm 3.31$ & 92 & 0.01 & 0.001 & 58.6 & 0.06 \\
\hline Chloride (mg/l) & $59.3 \pm 8.49$ & 600 & 0.002 & 0.0002 & 9.89 & 0.002 \\
\hline \multirow[t]{3}{*}{$\mathrm{pH}$} & $6.93 \pm 0.12$ & 8.4 & 0.12 & 0.01 & -5 & -0.05 \\
\hline & & & $\Sigma 11.30$ & $\Sigma 1.00$ & & $\Sigma 67.10$ \\
\hline & & & K & & 0.088 & \\
\hline
\end{tabular}

Table 4. Water quality index at Site 3 revealed by physiochemical parameters.

\begin{tabular}{|c|c|c|c|c|c|c|}
\hline Parameter & Observed value (Vi) & Standard value $(\mathrm{Si})$ & $1 / \mathrm{Si}$ & $\mathrm{Wi}$ & Quality rating (Qi) & WiQi \\
\hline Fluoride (mg/l) & $0.63 \pm 0.59$ & 2 & 0.5 & 0.044 & 31.5 & 1.40 \\
\hline Iron (mg/l) & $0.15 \pm 1.36$ & 2 & 0.5 & 0.044 & 7.5 & 0.33 \\
\hline Manganese (mg/l) & $0.01 \pm 2.13$ & 0.1 & 10 & 0.89 & 10 & 8.86 \\
\hline Nitrate (mg/l) & $5.65 \pm 2.85$ & 30 & 0.03 & 0.003 & 18.8 & 0.06 \\
\hline Sodium (mg/l) & $87.13 \pm 5.83$ & 400 & 0.003 & 0.0002 & 21.78 & 0.47 \\
\hline Sodium absorption ratio & $3.41 \pm 4.47$ & 8 & 0.125 & 0.01 & 42.6 & 0.47 \\
\hline Sulphates (mg/l) & $30.41 \pm 6.52$ & 200 & 0.005 & 0.0004 & 15.21 & 0.007 \\
\hline Total dissolved solids (mg/l) & $602 \pm 30.3$ & 2000 & 0.0005 & 0.00004 & 30.1 & 0.001 \\
\hline Bicarbonate (mg/l) & $50.6 \pm 3.36$ & 92 & 0.01 & 0.001 & 55 & 0.05 \\
\hline Chloride (mg/l) & $58.57 \pm 7.21$ & 600 & 0.002 & 0.0002 & 9.76 & 0.001 \\
\hline \multirow[t]{3}{*}{$\mathrm{pH}$} & $6.72 \pm 0.32$ & 8.4 & 0.12 & 0.01 & -20 & -0.21 \\
\hline & & & $\Sigma 11.30$ & $\Sigma 1.00$ & & $\Sigma 11.0$ \\
\hline & & & $\mathrm{K}$ & 0.088 & & \\
\hline
\end{tabular}


who reported that as wastewater moved downstream, the pollution level gradually decreased from one point to another. The highest pollutant reductions observed were $97 \%, 86 \%$ and $70 \%$ respectively, for nitrates, manganese and iron.

The water quality index for site 4 was 542 which classified the effluent unsuitable for any purpose (Table 5). Animals, birds and rodents were observed frequenting the area and their droppings could have contributed to high WQI value. The concentrations of ions such as manganese, iron and bicarbonate were $0.6 \mathrm{mg} / \mathrm{l}, 3.3 \mathrm{mg} / \mathrm{l}$ and $270 \mathrm{mg} / \mathrm{l}$ compared to $0.01 \mathrm{mg} / \mathrm{l}, 0.25 \mathrm{mg} / \mathrm{l}$ and $50.6 \mathrm{mg} / \mathrm{l}$ observed at Site 3 respectively. These values were above the permissible limit and had increased by $5900 \%, 2100 \%$, and $434 \%$ respectively. The overall contribution of these three ions to WiQi was $99 \%$. Other ions such as chloride, sodium and $\mathrm{pH}$, increases were very insignificant. If it was not because of the pollution effect of the animals found at that point, the WiQi value could have been lower than at point 3 (11.0) indicating natural purification as effluent travels downstream. The previous studies by [14] have analysed the chemical composition of cow dung and reported concentrations as high as $58.86 \mathrm{ppm}$ of manganese.

WiQi values calculated using physiochemical parameters were found decreasing as effluent travelled downstream from outlet suggesting natural degradation of pollutants in the receiving environment.

\subsection{Microbiological Water Quality Index}

Microbiological water quality index at site 1 was 854 (Table 6) and the effluent is classed as unsuitable for use according to [15] classification. The high value at Site 1 indicates that the system was not able to reduce the bacterial loads to the

Table 5. Physiochemical parameters water quality index at Site 4.

\begin{tabular}{|c|c|c|c|c|c|c|}
\hline Parameter & $\begin{array}{l}\text { Observed } \\
\text { value }(\mathrm{Vi})\end{array}$ & $\begin{array}{l}\text { Standard } \\
\text { value }(\mathrm{Si})\end{array}$ & $1 / \mathrm{Si}$ & $\mathrm{Wi}$ & $\begin{array}{c}\text { Quality } \\
\text { rating }(\mathrm{Qi})\end{array}$ & WiQi \\
\hline Fluoride (mg/l) & $0.64 \pm 0.62$ & 2 & 0.5 & 0.044 & 32 & 1.42 \\
\hline Iron $(\mathrm{mg} / \mathrm{l})$ & $3.3 \pm 1.14$ & 2 & 0.5 & 0.044 & 165 & 7.31 \\
\hline Manganese (mg/l) & $0.6 \pm 2.83$ & 0.1 & 10 & 0.89 & 600 & 531.44 \\
\hline Nitrate $(\mathrm{mg} / \mathrm{l})$ & $4.87 \pm 1.91$ & 30 & 0.03 & 0.003 & 16.2 & 0.05 \\
\hline Sodium (mg/l) & $89.97 \pm 4.67$ & 400 & 0.003 & 0.0002 & 22.49 & 0.005 \\
\hline $\begin{array}{l}\text { Sodium absorption ratio } \\
(\mathrm{mg} / \mathrm{l})\end{array}$ & $2.94 \pm 5.72$ & 8 & 0.13 & 0.01 & 36.75 & 0.41 \\
\hline Sulphates (mg/l) & $30 \pm 6.38$ & 200 & 0.005 & 0.0004 & 15 & 0.007 \\
\hline Total dissolved solids (mg/l) & $554 \pm 26.5$ & 2000 & 0.0005 & 0.00004 & 27.7 & 0.001 \\
\hline Bicarbonate (mg/l) & $270.1 \pm 2.56$ & 92 & 0.01 & 0.001 & 293.59 & 0.28 \\
\hline Chloride (mg/l) & $82.91 \pm 5.23$ & 600 & 0.002 & 0.0002 & 13.82 & 0.002 \\
\hline \multirow[t]{3}{*}{$\mathrm{pH}$} & $8.09 \pm 0.21$ & 8.4 & 0.12 & 0.01 & 77.86 & 0.82 \\
\hline & & & $\Sigma 11.30$ & $\Sigma 1.00$ & & $\Sigma 137.79$ \\
\hline & & & K & 0.088 & & 541.74 \\
\hline
\end{tabular}


required limits. The WQI at Site 2 was 141.60 (Table 6) which is categorised as unsuitable for domestic and agricultural purposes similar to Site 1. However, the concentrations of the observed values reduced in the effluent. The quality from Site 1 to Site 2 improved as observed from an initial WiQi value of 854 to 142 (83\%). Of the parameters used for calculating WQI, two (E. coli and total coliforms) had concentrations lower than the standard values. The remaining two, (faecal coli and faecal streptococci) had concentrations above the thresholds which contributed to higher WiQi of combined value of 124 or $88 \%$ of the total. In increasing order, the reductions of parameters at Site 2 were 91\%, 93\%, 98\% and $98 \%$ respectively, for faecal streptococci, total coliforms, faecal coliforms and $E$. coli. These reductions could be due to natural degradation of microorganisms.

The Water quality index at Site 3 was 96 (Table 6) and categorised as poor quality and possible usage can be irrigation. The WQI value reduced between sites 2 and 3 by $32 \%$, thus a quality improvement. In increasing order, individual parameters between the two sites reduced by $6 \%, 32 \%, 39 \%$ and $94 \%$ respectively for E. coli, faecal coli, faecal streptococci and total coliforms respectively. Except for faecal Streptococci, all the other parameters were within the threshold limits. Reference [16] reported that faecal streptococci outlive faecal coliforms in effluents and aquatic environments and more resistant to sunlight inactivation. [17] reported that faecal streptococci mortality rate was less than that of faecal coliform. This was true for this study as faecal streptococci were found to be the most concentrated and above threshold as effluent moved downstream from Site 1 to 3 . This suggests that there was an improvement in quality as effluent moved downstream. These results were similar to the physiochemical water quality index results observed earlier.

All the four microbiological parameters were far much higher than the thresholds. In increasing order, the observed concentrations at Site 1 were 263,200, $33,050,31,800$, and $26,000 \mathrm{CFU} / 100 \mathrm{ml}$ (Table 7) and corresponding thresholds were $20,000,1000,500$, and $1000 \mathrm{CFU} / 100 \mathrm{ml}$ (not shown) respectively. As for

Table 6. Microbiological water quality indices at Sites 1, 2, 3 and 4.

\begin{tabular}{ccccc}
\hline Site & Site 1 & Site 2 & Site 3 & Site 4 \\
\hline WiQi & 854 & 142 & 96 & 1539 \\
\hline
\end{tabular}

Table 7. Microbiological parameters observed at Sites 1, 2, 3 and 4.

\begin{tabular}{ccccc}
\hline \multirow{2}{*}{ Parameter } & \multicolumn{3}{c}{ Observed value } \\
\cline { 2 - 4 } & Site 1 & Site 2 & Site 3 & Site 4 \\
\hline E. coli & $33,050 \pm 11$ & $670 \pm 7$ & $630 \pm 5$. & $34,600 \pm 13$ \\
FC & $31,800 \pm 9$ & $680 \pm 7$ & $460 \pm 6$ & $0 \pm 0.00$ \\
TC & $263,200 \pm 15$ & $17,990 \pm 18$ & $1050 \pm 11$ & $55,400 \pm 21$ \\
FS & $26,000 \pm 9$ & $2300 \pm 3$ & $1400 \pm 4$ & $27,600 \pm 10$ \\
\hline
\end{tabular}


Site 2 observed concentrations were 17,990, 2300, 680, and $670 \mathrm{CFU} / 100 \mathrm{ml}$ for total coliforms, faecal streptococci, faecal coli, and E. coli respectively. The corresponding observed values for site 3 were 1050, 1400, 460 and $630 \mathrm{CFU} / 100 \mathrm{ml}$ respectively. Threshold values for these bacteriological indicators were 20,000, 1000, 500 and $500 \mathrm{CFU} / 100 \mathrm{ml}$ respectively, for total coliforms, faecal streptococci, faecal coli, and E. coli.

The water quality index at site 4 was 1539 (Table 6) and very high compared to the other sites. Droppings of animals such as cows, birds and rodents found at the site contributed to increased water quality index. It has been reported that faecal streptococci population can be $1.3 \times 10^{6}$ in cow faeces [16]. The highest contributors to WQI were E. coli and faecal streptococci and these organisms are usually abundant in animal faeces. From Site 3 to 4 , E. coli, total coli and faecal streptococci had increased by 33,970, 54,350 and 26,200 CFU/100ml respectively, indicating that animal faeces could have increased the concentrations of these microorganisms.

E. coli and faecal streptococci contributed $55 \%$ and $44 \%$ of the total WQI for site 4 which was $99 \%$ of the total. It has been reported that faecal streptococci are more resistant compared to coliforms with their mortality rates lower. Faecal coli was not detected at Site 4 suggesting that their mortality rate was high compared to the other microorganisms.

\subsection{Soil Analysis}

Table 8 shows the concentrations of different parameters analysed from soil samples at the four different sites. There was a decrease or increase in concentrations as effluent moved downstream from Site 1. The percent reductions were $15.5 \%, 57 \%, 81.6 \%, 93.5 \%, 93.5 \%$ and $99 \%$ respectively, for magnesium, zinc, lead, sodium adsorption ratio, sodium and electrical conductivity. These parameters were retained by soil from the effluent. In the case of iron and calcium ions it was observed that instead there were increases in concentrations as effluent moved downstream from discharge point. The percent increases were $21.4 \%$ and $185 \%$ respectively, for calcium and iron ions.

Table 8. Concentrations of different parameters in soil at different sites.

\begin{tabular}{ccccc}
\hline Parameter & Site 1 & Site 2 & Site 3 & Site 4 \\
\hline Electricity conductivity $(\mu \mathrm{S} / \mathrm{cm})$ & $3120 \pm 0.32$ & $2140 \pm 0.29$ & $158 \pm 0.24$ & $32 \pm 0.12$ \\
Sodium $(\mathrm{mg} / \mathrm{l})$ & $674.3 \pm 0.71$ & $588.2 \pm 0.43$ & $71.0 \pm 0.35$ & $44.1 \pm 0.48$ \\
Calcium $(\mathrm{mg} / \mathrm{l})$ & $14.8 \pm 0.13$ & $21.7 \pm 0.03$ & $20.9 \pm 0.05$ & $42.2 \pm 0.22$ \\
Magnesium $(\mathrm{mg} / \mathrm{l})$ & $160.8 \pm 4.26$ & $189.5 \pm 5.65$ & $121.3 \pm 5.31$ & $135.8 \pm 5.27$ \\
Sodium adsorption ratio & $72.0 \pm 0.17$ & $57.0 \pm 0.13$ & $8.43 \pm 0.11$ & $4.67 \pm 0.01$ \\
Iron $(\mathrm{mg} / \mathrm{l})$ & $3975 \pm 0.21$ & $5430 \pm 0.38$ & $3250 \pm 0.25$ & $4825 \pm 0.41$ \\
Lead $(\mathrm{mg} / \mathrm{l})$ & $15.8 \pm 0.56$ & $1.6 \pm 0.12$ & $4.0 \pm 0.05$ & $2.9 \pm 0.03$ \\
Zinc $(\mathrm{mg} / \mathrm{l})$ & $7.9 \pm 0.01$ & $5.3 \pm 0.05$ & $3.5 \pm 0.05$ & $3.4 \pm 0.04$
\end{tabular}




\subsubsection{Electrical Conductivity}

The electrical conductivity (EC) decreased downstream from Sites 1, 2, 3 and 4 by values of $3120,2140,158$ and $32 \mu \mathrm{S} / \mathrm{cm}$, respectively. This was a $99 \%$ reduction in concentration. The high value of EC at Site 1 could have been due to high concentration of cations in the effluent discharged and accumulating at the point. The results show that EC was reduced as effluent travelled further away from the point. This could be due to adsorption of cations on negatively charged colloids and could be true for this study. As effluent moved through soil, cations were absorbed by negatively charged colloids present in the effluent. Cations such as sodium, magnesium, lead and zinc were retained by soil hence decrease in the EC of the soil. These results are comparable to the findings by [18] who reported electrical conductivity of $60.5 \mu \mathrm{S} / \mathrm{cm}$ at the sewage discharge point and $52.1 \mu \mathrm{S} / \mathrm{cm}$ downstream. Reference [19] reported that any effluent having EC higher than $1000 \mu \mathrm{S} / \mathrm{cm}$ could affect the physicochemical properties of soil. In this work the effluent EC concentration (not shown) was $514 \mu \mathrm{S} / \mathrm{cm}$, therefore might not affect soils but with time can lead to the cations accumulation in the soil hence saturation and higher EC values even downstream of the discharge point.

\subsubsection{Sodium Adsorption Ratio}

The sodium adsorption ratio (SAR) was decreasing downstream of site 1 as values of 72.0, 57, 8.43 and 4.67 were observed for Sites 1, 2, 3 and 4 respectively. The decrease was correlating with sodium concentration which decreased as $674.3,588.2,71.0$, and $44.1 \mathrm{mg} / 1$ at Sites 1, 2, 3 and 4 respectively. SAR is a ratio of exchangeable sodium ions to calcium and magnesium ions which tends to influence soil properties. A high SAR (>15) causes dispersal of soil particles [20]. It was observed that the calculated SAR value for site 1 was higher (72) which could disperse soil properties. It has been reported by [21] that the application of medium to high SAR water reduces the total depth of infiltration and infiltration rate. This could be the consequences if the effluent in this study was used for irrigation purposes as the threshold limit is 8 and effluent value was 72 .

\subsubsection{Metals}

The results of metals concentrations in the soil at different sites are shown in Table 8. The concentrations of sodium, magnesium, lead and zinc ions at Sites 2, 3 and 4 were lower than at Site 1 . Site 1 was found to have higher concentrations of these metals compared to other sides downstream. Since this was the discharge point of the wastewater treatment, it was expected that there would be more accumulation of the metals in the soil near the discharge point. As effluent travelled downstream, there would be a decrease in concentrations because of adsorption, hydrolysis and co-precipitation effects and deposition on the sediment [5]. Similar results were observed by [5] who studied the concentrations of some metals along Tigris River downstream of wastewater discharge from a copper mine. During this study, iron and calcium ion concentrations were increasing downstream of the discharge point. In addition, iron was found to have higher concentrations compared to the other metals. The same was observed by 
[5]. Other contributions of iron and calcium in the sediment could be natural from the weathering of rocks and soil in the area. This study also showed that in increasing order, the concentrations of the metals at Site 4 were in the order iron $>$ magnesium $>$ sodium $>$ calcium $>$ zinc $>$ lead. Reference [22] reported that sediments extracted from areas irrigated with wastewater effluent had higher metal concentrations than controls which were not exposed to wastewater. It was concluded that wastewater effluents contributed to high concentrations of metals in sediments. Heavy metals such as zinc, lead and iron can accumulate into aquatic life and ultimately find their way to humans through food chain and cause health problems. Treated wastewater from this particular treatment system has been suggested for irrigational purposes. This, however, might pose a risk to human health because metals in treated wastewaters significantly increase their content in irrigated soils and they are transferred to plants and food chain [23]. The high concentrations of these metals from the treatment system may have direct effects on the growth of crops while some may affect human health.

\section{Conclusion}

This study assessed the quality of effluent from waste stabilisation ponds system and in the receiving environment through the calculation of physiochemical and microbiological water quality indices. The water quality index for the treatment works showed that the effluent was unsuitable for disposal into the environment and needs further treatment. However, samples at intervals of $100 \mathrm{~m}$ from discharge point showed some improvement in quality due to natural processes except $400 \mathrm{~m}$ away from where the effluent was contaminated by animals' faeces. Soil analysis showed that metals were retained by the soil and their concentrations decreased further down the discharge point except iron and calcium which increased downstream. The effluent needs further polishing before discharge into the environment.

\section{Acknowledgements}

This work was funded by Botswana International University of Science and Technology through grant initiation programme [grant number 10/2016]. The authors are thankful to the Water Utilities Corporation and their technical staff for allowing us to conduct research on their facility and they provided.

\section{Funding}

This study was funded by Botswana International University of Science and Technology through postgraduate research grant in 2016.

\section{Conflicts of Interest}

The authors declare no conflicts of interest regarding the publication of this paper. 


\section{References}

[1] Misaghi, F., Delgosha, F., Razzaghmanesh, M. and Myers, B. (2017) Introducing a Water Quality Index for Assessing Water for Irrigation Purposes: A Case Study of the Ghezel Ozan River. Science of the Total Environment, 589, 107-116.

[2] Koçer, M.A.T. and Sevgili, H. (2014) Parameters Selection for Water Quality Index in the Assessment of the Environmental Impacts of Land-Based Trout Farms. Ecological Indicators, 36, 672-681.

[3] Zahedi, S. (2017) Modification of Expected Conflicts between Drinking Water Quality Index and Irrigation Water Quality Index in Water Quality Ranking of Shared Extraction Wells Using Multi Criteria Decision Making Techniques. Ecological Indicators, 83, 368-379. https://doi.org/10.1016/j.ecolind.2017.08.017

[4] Brhane, G.K. (2016) Irrigation Water Quality Index and GIS Approach based Groundwater Quality Assessment and Evaluation for Irrigation Purpose in Ganta Afshum Selected Kebeles, Northern Ethiopia. International Journal of Emerging Trends \& Technology in Computer Science, 4624-4636.

[5] Varol, M. and Şen, B. (2012) Assessment of Nutrient and Heavy Metal Contamination in Surface Water and Sediments of the Upper Tigris River, Turkey. Catena, 92, 1-10. https://doi.org/10.1016/j.catena.2011.11.011

[6] Tyagi, S., Sharma, B., Singh, P. and Dobhal, R. (2013) Water Quality Assessment in Terms of Water Quality Index. American Journal of Water Resources, 1, 34-38.

[7] Rai, R.K. and Upadhyay, A. (2013) Brief Overview of the Yamuna River Basin and Issues. In: Water Management and Public Participation. SpringerBriefs in Earth Sciences, Springer, Dordrecht, 13-24. https://doi.org/10.1007/978-94-007-5709-7_2

[8] Bouslah, S., Djemili, L. and Houichi, L. (2017) Water Quality Index Assessment of Koudiat Medouar Reservoir, Northeast Algeria Using Weighted Arithmetic Index Method. Journal of Water and Land Development, 35, 221-228. https://doi.org/10.1515/jwld-2017-0087

[9] Dalal, R.C. and Henry, R.J. (1986) Simultaneous Determination of Moisture, Organic Carbon, and Total Nitrogen by Near Infrared Reflectance Spectrophotometry. Soil Science Society of America Journal, 50, 120-123. https://doi.org/10.2136/sssaj1986.03615995005000010023x

[10] Shanbehzadeh, S., Vahid Dastjerdi, M., Hassanzadeh, A. and Kiyanizadeh, T. (2014) Heavy Metals in Water and Sediment: A Case Study of Tembi River. Journal of Environmental and Public Health, 2014, Article ID: 858720. https://doi.org/10.1155/2014/858720

[11] Pierzynski, G.M., Sims, J.T. and Vance, G.F. (2005) Soils and Environmental Quality. Taylor \& Francis, New York, 313.

[12] Khwakaram, A., Majid, S.N., Ahmed, Z.H. and Hamasalih. N. (2015) Application of Water Quality Index (WQI) as a Possible Indicator for Agriculture Purpose and Assessing the Ability of Self Purification Process by Qalyasan Stream in Sulaimani City, Iraqi/Kurdistan Region (IKR). International Journal of Plant, Animal and Environmental Sciences, 5, 162-173.

[13] Bora, M. and Goswami, D.C. (2016) Water Quality Assessment in Terms of Water Quality Index (WQI): Case Study of the Kolong River, Assam, India. Applied Water Science, 7, 3125-3135. https://doi.org/10.1007/s13201-016-0451-y

[14] Ntui, N.T., Hassan, U.F. and Ushie, O.A. (2014) Determination of Heavy Metals Concentration in Cow Dung of Grazing Cattle in Bauchi Urban Area, Nigeria. International Journal of Modern Analytical and Separation Sciences, 3, 13-19. 
[15] Brown, R.M., McClelland, N.I., Deininger, R.A. and Connor, M.F.O. (1972) A Water Quality Index -Crashing the Psychological Barrier. In: Thomas, W.A., Ed., Indicators of Environmental Quality, Springer, Boston, MA, 173-182. https://doi.org/10.1007/978-1-4684-1698-5_15

[16] Sinton, L.W., Donnison, A.M. and Hastie, C.M. (1993) Faecal Streptococci as Faecal Pollution Indicators: A Review. Part II : Sanitary Significance, Survival, and Use. New Zealand Journal of Marine and Freshwater Research, 27, 117-137. https://doi.org/10.1080/00288330.1993.9516550

[17] Howell, J.M., Coyne, M.S. and Cornelius, P.L. (1996) Effect of Sediment Particle Size and Temperature on Fecal Bacteria Mortality Rates and the Fecal Coliform/Fecal Streptococci Ratio. Journal of Environmental Quality, 25, 1216-1220.

[18] Island, W., State, B., Island, W. and State, B. (2013) Soil Contamination from Cassava Wastewater Discharges in a Rural Community in the Soil Contamination from Cassava. Journal of Applied Sciences and Environmental Management, 17, 105-110.

[19] Attah, L.E. and Melkamu, B.R. (2013) Assessment of Heavy Metals, pH and EC in Effluent Run-off, River and Adjacent Soil Around a Floriulature Industry in Holeta, Welmera District, Ethiopia. Ethiopian Journal of Environmental Studies and Management, 6, 620-629. https://doi.org/10.4314/ejesm.v6i6.5

[20] Acton, A. (2012) Advances in Research and Application: 2012 Edition. Google Books, 152.

[21] Aboukarima, A.M., Al-Sulaiman, M.A., El Marazky, M.S.A. (2018) Effect of Sodium Adsorption Ratio and Electric Conductivity of the Applied Water on Infiltration in a Sandy-Loam Soil. Water SA, 44, 105-110. https://doi.org/10.4314/wsa.v44i1.12

[22] Mekki, A. and Sayadi, S. (2017) Study of Heavy Metal Accumulation and Residual Toxicity in Soil Saturated with Phosphate Processing Wastewater. Water, Air, \& Soil Pollution, 228, 215. https://doi.org/10.1007/s11270-017-3399-0

[23] Nan, Z., Li, J., Zhang, J. and Cheng, G. (2002) Cadmium and Zinc Interactions and Their Transfer in Soil-Crop System under Actual Field Conditions. Science of The Total Environment, 285, 187-195. https://doi.org/10.1016/S0048-9697(01)00919-6 